\title{
QK232
}

- B7

1915

Britton, N L

The vegetation of Mona Island 


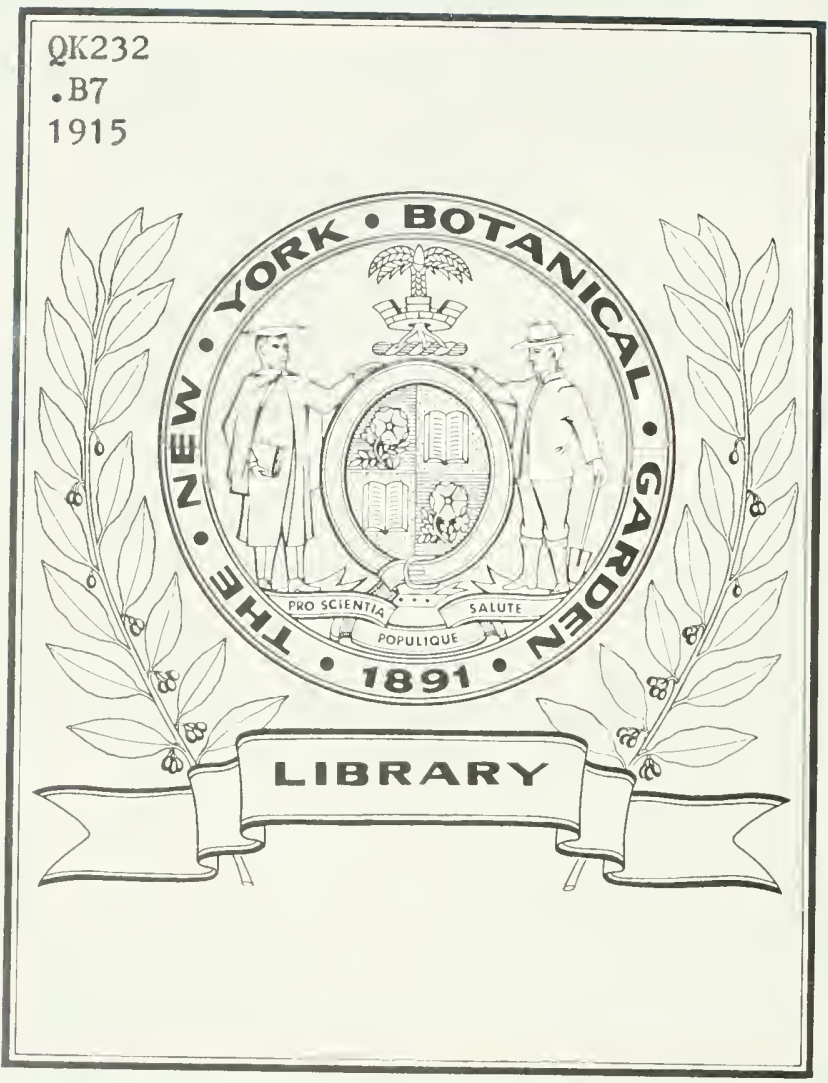




CONTRIBUTIONS FROM THE NEW YORK BOTANICAL

GARDEN-No. 175

\section{THE VEGETATION OF MONA ISLAND}

A paper read by invitation at the Twenty-Fifth Anniversary Celebration of the Missouri Botanical Garden, October 15, 1914

\section{NATHANIEL LORD BRITTON}

ST. LOUIS

1915

Reprinted without change of paging from ANNALS OF THE. MISSOURI BOTANICAL GARDEN 2: 33-58. May, 1915. 



\title{
THE VEGETATION OF MONA ISLAND ${ }^{1}$
}

\author{
N. L. BRITTON \\ New York Botanical Garden
}

During the progress of the scientific survey of Porto Rico, organized by the New York Academy of Sciences with the aid of the American Museum of Natural History, the New York Botanical Garden and Columbia University, in coöperation with the Porto Rican Insular Government, exploration has been carried out not alone on the mainland of Porto Rico but on several small islands adjacent and politically a part of that colony. Two of these islands lie in the Mona Passage between Porto Rico and Santo Domingo, and being scientifically almost unknown, were made points of examination in February, 1914, when I visited them in company with Mr. John F. Cowell, Director of the Buffalo Botanic Garden, Dr. Frank E. Lutz, Assistant Curator of Invertebrate Zoölogy in the American Museum of Natural History, and Mr. W. E. Hess, Plant Propagator of the Porto Rico Agricultural Experiment Station at Mayaguez. The trip was made in a sloop chartered at Mayaguez.

Desecheo Island, lying about eighteen miles northwest of Mayaguez, was first visited, and explored during two days; this island is somewhat more than one square mile in area, bordered by rocky coasts, rising abruptly into several hills, and covered with low trees and shrubs. Its flora is essentially identical with that of the drier parts of Porto Rico and of Santo Domingo; the small tree Morisonia americana and the snowy cactus (Mamillaria nivosa) have, however, not yet been found on the Porto Rican mainland, although both occur on the Island of Culebra east of Porto Rico, and neither of them is known on Santo Domingo. The cactus Opuntia haitiensis, plentiful there, is otherwise known only in Hispaniola, and the shrub Torrubia discolor of Hispaniola and Cuba has not been found on Porto Rico. The collection made

${ }^{1}$ Issued May 17, 1915.

ANN. Mo. Bot. Gard., Vol. 2, 1915 
by us on Desecheo, together with one made by Professor F. L. Stevens and Mr. W. E. Hess in May, 1913, shows that the spermatophytes of Desecheo number about 90 species; further intensive exploration might reveal a few more. A single species of fern was seen, four species of mosses, and two species of hepatics. As there is no probability of this little island ever having been a part of the Porto Rico mainland, its plants must have reached it by natural agencies; there are probably as many fungi and lichens as of other land plants collectively, so the total land flora of Desecheo probably includes at least 200 species.

Mona Island, lying about thirty miles to the southwest of Desecheo, in the middle of the Mona Passage between Santo Domingo and Porto Rico, has an area of approximately twenty square miles. Prior to our visit, only one botanical collection had been made there, when it was visited by Professor F. L. Stevens in 1913, at which time he obtained specimens of about 150 species of flowering plants, and gave especial attention to the parasitic fungi. The considerable land area of this island made a complete knowledge of its flora desirable, from the standpoint of geographical distribution of West Indian plants, and we were able to devote five days to collecting. The greater portion of Mona is a limestone plateau elevated from 125 to 175 feet, the surface of this plateau being nearly level and devoid of hills; its soil is very sparse, consisting altogether of reddish loam in depressions of the limestone surface, and not of considerable extent at any point visited by us. The limestone is evidently very porous, and there are no streams or ponds, and only a single spring was seen; the limestone is honeycombed with caves and caverns, some of them of considerable size. The rainfall is evidently considerable, but there are no records of its amount. Despite the paucity of soil, the whole plateau is rather densely covered with shrubs and low trees of a considerable number of species, their roots, for the most part, penetrating into crevices of the limestone. Herbaceous vegetation is restricted to comparatively few species. Eight species of cacti inhabit this plateau, and in places are very abundant, the snowy cactus 
(Mamillaria nivosa) being more plentiful here than on any other island visited by us; Opuntia Taylori, hitherto known from Hispaniola, Culebra and the Virgin Islands, was found as a single colony; this has not yet been detected on the Porto Rican mainland.

The limestone plateau of Mona is bordered nearly throughout by steep escarpments and is accessible at but few points, except along the southwestern side, where there is a low plain several miles long and averaging about half a mile wide, from which the plateau is reached at a number of points over a talus of large limestone blocks. At the foot of the escarpment and of the talus on this southwestern side, the moistest conditions of Mona occur, and several species of trees here reach large size, notably the manchioneel (Hippomane Mancinella) and two species of Ficus. Here also grow two species of ferns, several bryophytes, and a number of Polyporaceae infesting dead wood. The soil of the narrow plain is more abundant than that of the plateau, permitting agricultural operations on a small scale and supporting a low forest made up of a considerable number of kinds of trees, with more herbaceous vegetation than exists on the plateau. Among rare elements of this vegetation are two orchids, Domingoa hymenodes, hitherto known from Hispaniola and Cuba, and Ibidium lucayanum, of Porto Rico, Anagada and the Bahamas. The coastal sands, which extend almost uninterruptedly along the shore of the plain, are inhabited by characteristic West Indian sand-dune species.

Lichens are quite abundant on tree trunks and on rocks of the talus, including a considerable number of species. Professor Lincoln W. Riddle has examined the collection and has submitted the following report upon them:

"The exploration of Mona Island has yielded 42 numbers of lichens, 40 collected by Dr. N. L. Britton, Messrs. J. F. Cowell and W. E. Hess, and 2 collected incidentally by Dr. F. L. Stevens. These 42 numbers represent 26 species in condition for determination.

"The species growing on the limestone rocks constitute the most striking and interesting part of the collection. These include four species of Omphalaria, a species of Collema, and a species of the Dermatocarpaceae, which is, unfortunately, sterile and, therefore, not further determinable. The omphalarias are all little known species. 
O. polyglossa $\mathrm{Nyl}$., collected from limestone rocks in Cuba by Charles Wright, and not otherwise known, is apparently common on Mona Island, as it is represented by two numbers, each with several welldeveloped specimens. There occur also $O$. lingulata Tuck., previously known from Cuba and Bermuda; a sterile omphalaria related to $O$. Wrightii Tuck., but apparently not identical; and one other species of the genus, probably new. It has not yet been possible to identify the species of Collema, and that may also prove to be new. Curiously enough, none of these calciphile species has yet been detected among the material collected in Porto Rico.

"In marked contrast to the rock-lichens, the bark-inhabiting lichens are all common species, widely distributed in Tropical America. The genus Trypethelium is best represented, with the species $T$. Eluteriae (four numbers), T. ochroleucum, and its variety pallescens, and T. mastoideum (two numbers). There are also such characteristic species as Graphis Afzelii, Melanotheca cruenta, Pyxine picta, Physcia alba and P. speciosa, Parmelia sulphurata and P. tinctorum, and Ramalina complanata and $R$. Montagnei. Probably owing to the comparatively unfavorable conditions on Mona Island, the foliose and fruticose lichens are mostly small specimens, not well-developed."

The total flora of flowering plants, as indicated by the collection made by Professor Stevens and our own, includes about 230 species; some of them are found only in cultivated grounds on the coastal plain and have probably been introduced by man. The total flora of land cryptogams is probably as great or greater than that of flowering plants, so we may conclude that the land flora of Mona consists of as high as 500 species. So far as the investigation of the collections has proceeded, the only apparent endemic species are a Chamaesyce, which Dr. C. F. Millspaugh has described as new, a Tabebuia, the description of which is herewith included, and two very interesting riccias, here described by Dr. Marshall A. Howe. One or more of the lichens may be undescribed. Further exploration in Porto Rico and in Hispaniola may very well reveal their presence on these larger islands. It is interesting to have ascertained that the flora of this isolated limestone island is not more highly specialized. It is not necessary, in my opinion, to assume a former land connection between Mona and either Porto Rico or Santo Domingo, because all its native species may readily have reached it through natural agencies. 
I append a list of the species collected as thus far determined, and have indicated in this list their known distribution, except that of the lichens and Uredinales, as regards Porto Rico, Curaçao, Hispaniola and the Bahamas, the nearest lands to Mona.

The names of new species, and new binomials, are printed in heavy face type.

\section{List of Species inhabiting Mona Island}

\section{MONOCOTYLEDONS}

VALOTA INSULARIS (L.) Chase

Common on the coastal plain and on the plateau: Porto Rico; Hispaniola; Bahamas; Curacao.

SYNTHERISMA DIGITATUM (Sw.) Hitchc.

Frequent in cultivated ground, coastal plain: Porto Rico; Hispaniola; Bahamas.

PASPALUM CAESPITOSUM Fluegge Bahamas.

Frequent on the coastal plain and on the plateau: Porto Rico; Hispaniola;

\section{PASPALUM SIMPSONI Nash}

Collected by Professor Stevens, not found by us: Porto Rico; Bahamas.

PANICUM UTOWANAEUM Scribn.

Frequent on the coastal plain and on the plateau: Porto Rico; Desecheo; [Cuba; Guadeloupe].

PANICUM BARBINODE Trin.

Sandy soil, Playa de Fajaro: native of South America. Naturalized in the West Indies.

\section{PANICUM ADSPERSUM Trin.}

Moist soil, coastal plain: Porto Rico; Bahamas.

PANICUMI MAXIMUM Jacq.

Frequent on the coastal plain: Native of tropical Africa; naturalized in the West Indies.

\section{LASIACIS DIVARICATA (L.) Hitchc.}

Frequent in thickets, coastal plain and plateau: Porto Rico; Hispaniola; Bahamas.

CHAETOCHLOA SETOSA (Sw.) Scribn.

Frequent on the coastal plain: Porto Rico; Hispaniola; Bahamas; Curacao.

CHAETOCHLOA CAUdATA (Lam.) Scribn.

Occasional on the coastal plain: Desecheo; [Jamaica; Cuba; St. Thomas].

CHAETOCHLOA. IMBERBIS (Poir.) Scribn.

Frequent on the coastal plain: Porto Rico; Hispaniola; Bahamas.

CENCHROPSIS MYOSUROIDES (HBK) Nash

Frequent in cultivated ground on the coastal plain: Bahamas; Cuba. 


\section{CENCHRUS ECHINATUS L.}

Common on the coastal plain and on sand dunes: Porto Rico; Hispaniola; Bahamas; Curacao.

CENCHRUS CAROLINIANUS Walt.

Collected by Professor Stevens, not found by us: Porto Rico; Hispaniola; Bahamas; Curacao.

ARISTIDA BROMOIDES HBK.

Common on the coastal plain: Porto Rico; Bahamas; Curacao.

SPOROBOLUS VIRGINICUS (L.) Beauv.

Common on coastal sands and on the coastal plain: Porto Rico; Hispaniola; Bahamas.

SPOROBOLUS ARGUTUS (Nees) Kunth

Frequent in moist soil on the coastal plain: Porto Rico; Hispaniola; Curacao.

CHLORIS PARAGUAIENSIS Steud.

Coastal plain, Sardinera: Porto Rico; Hispaniola; Bahamas; Curacao.

EUSTACHYS PETRAEA (Sw.) Desv.

Common on coastal sands and on the coastal plain: Porto Rico; Hispaniola; Bahamas.

ELEUSINE INDICA (L.) Gaertn. Curacao.

Cultivated ground, coastal plain: Porto Rico; Hispaniola; Bahamas;

DACTYLOCTENIUM AEGYPTIUM (L.) Willd. Curacao.

Cultivated ground, coastal plain: Porto Rico: Hispaniola; Bahamas;

\section{PAPPOPHORUM LAGUROIDEUM Schrad.}

Wet soil, constal plain, between Sardinera and Ubero: Desecheo [Cuba; St. Eustatius].

ERAGROSTIS CILIARIS (L.) Link

Common on the coastal plain: Porto Rico; Hispaniola; Bahamas; Curacao.

CYPERUS ELEGANS L.

Border of a marsh on the coastal plain: Porto Rico; Hispaniola; Bahamas; Curacao.

CYPERUS TENUIS Sw.

Occasional on the coastal plain: Porto Rico; Hispaniola.

CYPERUS LIGULARIS L.

Marsh, Sardinera: Porto Rico; Hispaniola; Bahamas; Curacao.

CYPERUS BRUNNEUS Sw.

Common on coastal sands: Porto Rico; Bahamas; Hispaniola; Curacao.

FIMBRISTYLIS SPATHACEA Roth.

Common on the coastal plain: Porto Rico; Bahamas; Hispaniola.

SCLERIA LITHOSPERMA (L.) Sw.

Frequent on the coastal plain and on the plateau: Porto Rico; Hispaniola; Bahamas.

? THRINAX PONCEANA O. F. Cook

Apparently this species, but determined from leaves only. Rare in thickets on the coastal plain, and not found either in flower or in fruit: Porto Rico.

TILLANDSIA UTRICULATA L.

Common on trees and on rocks: Porto Rico; Hispaniola; Bahamas; Curacao. 
TILLANDSIA RECURVATA L.

Common on trees and shrubs: Porto Rico; Hispaniola; Bahamas; Curacao.

CALLISIA REPENS L.

Occasional on the coastal plain and on the plateau: Porto Rico; Hispaniola; Curacao.

COMMELINA VIRGINICA L. (C. elegans HBK.)

Frequent on the coastal plain: Porto Rico; Hispaniola; Bahamas; Curacao.

HYMENOCALLIS EXPANSA Herb.

Frequent in coastal sands. Determination from foliage only, therefore uncertain.

FURCRAEA TUBEROSA Ait. f.

Coastal plain between Sardinera and Ubero; probably introduced from Porto Rico. Determined from leaf specimens only: Porto Rico.

\section{IBIDIUM LUCAYANUM Britton}

Low woods, coastal plain near Sardinera: Porto Rico; Bahamas.

EPIDENDRUM PAPILIONACEUM Vahl

Common on shrubs and on the ground, coastal plain and plateau: Porto Rico; Hispaniola; recorded from the Bahamas.

DOMINGOA HYMENODES (Rchb. f.) Schltr.

On small trees between Sardinera and Ubero: Hispaniola [Cuba].

\section{DICOTYLEDONS}

PEPEROMIA HUMILIS (Vahl) A. Dietr.

Shaded limestone rocks near Sardinera. Plants with only the upper leaves opposite: Porto Rico; Hispaniola.

CELTIS TRINERVIA Lam.

Base of cliffs, Sardinera: Porto Rico; Hispaniola.

FICUS LAEVIGATA Vahl

Coastal plain and plateau; largest at the bases of cliffs: Porto Rico; Hispaniola.

FICUS STAHLII Warb.

Frequent along the bases of cliffs, eastern edge of the coastal plain. Trees up to $12 \mathrm{~m}$. high. Determined from foliage only: Porto Rico.

CHLOROPHORA TINCTORIA (L.) Gaud.

Base of cliffs, Sardinera: Porto Rico; Hispaniola.

PILEA TRIANTHEMOIDES (Sw.) Lindl.

Frequent on the coastal plain: Porto Rico.

PILEA MICROPHYLLA (L.) Liebm.

Occasional on the plateau: Porto Rico; Hispaniola; Bahamas; Curacao.

COCCOLOBIS UVIFERA (L.) Jacq.

Common on coastal sands and rocks: Porto Rico; Hispaniola; Bahamas; Curacao.

COCCOLOBIS OBTUSIFOLIA Jacq.

Common on the coastal plain and on the plateau: Porto Rico; Hispaniola; ? Bahamas.

COCCOLOBIS LAURIFOLIA Jacq.

Common on the coastal plain and on the plateau: Porto Rico; Hispaniola; Bahamas. 
COCCOLOBIS NIVEA Jacq.

Base of cliff, Sardinera: Porto Rico; Hispaniola.

AMARANTHUS TRISTIS L.

Waste and cultivated grounds on the coastal plain: Porto Rico; Hispaniola; Bahamas; Curacao.

ACHYRANTHES INDICA (L.) Mill.

Frequent in cultivated ground, coastal plain: Porto Rico; Hispaniola; Bahamas; Curacao.

\section{LITHOPHILA MUSCOIDES Sw.}

Collected by Professor Stevens, not found by us: Porto Rico; Hispaniola; Bahamas; Curacao.

CELOSIA NITIDA Vahl

Frequent on the coastal plain: Porto Rico; Hispaniola; Bahamas.

MIRABILIS JALAPA L

Waste grounds, uncommon: Porto Rico; Hispaniola; Bahamas.

BOERHAAVIA COCCINEA Mill.

Common on the coastal plain: Porto Rico; Hispaniola; Bahamas; Curacao.

? PISONIA SUBCORDATA Sw.

Base of cliffs, Sardinera. Trees, $12 \mathrm{~m}$. high or more, barren at the time of our visit and determination therefore uncertain: Porto Rico.

RIVINA HUMILIS L.

Common on the coastal plain on the plateau: Porto Rico; Hispaniola; Bahamas; Curacao.

TRICHOSTIGMA OCTANDRUM (L.) H. Walt.

Frequent on the talus, vicinity of Sardinera, forming vines $20 \mathrm{~m}$. long with trunks up to $1.5 \mathrm{dm}$. diameter: Porto Rico; Hispaniola.

PETIVERIA ALLIACEA L.

Occasional in thickets on the coastal plain: Porto Rico; Hispaniola; Bahamas.

SESUVIUM PORTULACASTRUM L.

Common on coastal rocks and sands: Porto Rico; Hispaniola; Bahamas; Curacao.

TALINUM PANICULATUM (Jacq.) Gaertn.

Coastal plain, Sardinera: Porto Rico; Hispaniola.

PORTULACA PHAEOSPERMA Urban

Moist soil, coastal plain and plateau: Porto Rico; Hispaniola; Bahamas; Curacao.

PORTULACA OLERACEA L.

Sandy soil, Playa de Fajaro: Porto Rico; Hispaniola; Bahamas; Curacao.

NECTANDRA CORIACEA (Sw.) Griseb. Base of limestone cliff, Sardinera: Porto Rico; Hispaniola; Bahamas; Curacao.

CASSYTHA AMERICANA Necs

Frequent on the coastal plain: Porto Rico; Hispaniola; Bahamas.

CLEOME GYNANDRA L.

Waste and cultivated grounds, coastal plain: Porto Rico; Hispaniola; Bahamas; Curacao.

CAPPARIS CYNOPHALLOPHORA L. (C. jamaicensis Jacq.)

Frequent on the coastal plain: Porto Rico; Hispaniola; Bahamas; Curacao. 
CAPPARIS FLEXUOSA L. (C. cynophallophora Jacq.)

Common on the coastal plain: Porto Rico: Hispaniola; Bahamas.

LEPIDIUM VIRGINICUM L.

Common in waste and cultivated ground: Porto Rico; Hispaniola; Bahamas.

BRASSICA INTEGRIFOLIA (West) O. E. Schulz

Occasional in cultivated ground, coastal plain: Porto Rico; Bahamas.

CAKILE LANCEOLATA (Willd.) O. E. Schulz

Common on coastal sands: Porto Rico; Hispaniola; Bahamas.

PITHECOLOBIUM UNGIUS-CATI (L.) Benth.

Common in coastal thickets and occasional on the coastal plain. All specimens examined were spineless: Porto Rico; Hispaniola; Bahamas; Curacao.

CASSIA OCCIDENTALIS L.

Sandy soil, Playa de Fajaro: Porto Rico; Hispaniola; Bahamas.

CHAMAECRISTA GRANULATA (Urban) Britton. (Cassia portoricensis granulata Urban.)

Common on the coastal plain and on sand dunes: Porto Rico.

CHAMAECRISTA DIFFUSA (DC.) Brittol. (Cassia diffusa DC.)

Collected by Professor Stevens, not found by us: Porto Rico; Curacao.

? CAESALPINIA DOMINGENSIS Urban

On the plateau, Sardinera. Determined from description: Hispaniola.

GUILANDINA CRISTA (L.) Small

Occasional in coastal thickets: Porto Rico; Hispaniola; Bahamas.

GUILANDINA MELANOSPERMA (Urban) Britton. (Caesalpinia melanosperma Urban.)

Frequent on the coastal plain: St. Croix.

GUILANDINA DIVERGENS (Urban) Britton

Frequent on the coastal plain: Culebra [St. Thomas].

KRAMERIA IXINA L.

Occasional on the coastal plain and on the plateau: Porto Rico; Hispaniola; Curacao.

INDIGOFERA SUFFRUTICOSA Mill Curacao.

Cultivated ground, coastal plain: Porto Rico; Hispaniola; Bahamas;

CRACCA CINEREA (L.) Morong

Common on the coastal plain and on the plateau: Porto Rico; Hispaniola; Bahamas; Curacao.

STYLOSANTHES HAMATA (L.) Taub.

l'requent on the coastal plain: Porto Rico; Hispaniola; Bahamas; Curacao.

MEIBOMIA SUPINA (Sw.) Britton

Frequent on the coastal plain and on the plateau: Porto Rico; Hispaniola; Bahamas; Curacao.

MEIBOMIA MOLLIS (Vahl) Kuntze

Occasional in cultivated ground on the coastal plain: Porto Rico; Hispaniola; Bahamas; Curacao.

BRADBURYA VIRGINIANA (L.) Kuntze

Common on the coastal plain and on the plateau: Porto Rico; Hispaniola; Bahamas. 
GALACTIA STRIATA (Jacq.) Urban

Frequent on the coastal plain and on the plateau. A race with small leaflets and slender-peduncled racemes: Porto Rico; Hispaniola.

CANAVALIA LINEATA (Thunb.) DC.

Common on coastal sands: Porto Rico; Hispaniola; Bahamas.

? DOLICHOLUS MINIMUS (L.) Medic

Cultivated ground, Ubero. A race apparently of this species, with thick leaflets, strongly veined; not found either in flower or in fruit, the determination, therefore, uncertain.

DOLICHOLUS RETICULATUS (Sw.) Millsp.

Common on the coastal plain and on the plateau: Porto Rico; Hispaniola; Bahamas.

ERYTHROXYLON AREOLATUM L. Bahamas.

Frequent on the coastal plain and on the plateau: Porto Rico; Hispaniola;

\section{GUAIACUM SANCTUM L.}

Frequent on the coastal plain: Porto Rico; Hispaniola; Bahamas; Curacao.

ZANTHOXYLUM PUNCTATUM Vahl

Coastal plain between Sardinera and Ubero: Porto Rico; Hispaniola.

AMYRIS ELEMIFERA L.

Occasional on the coastal plain: Porto Rico; Hispaniola; Bahamas.

SURIANA MARITIMA L.

Common on coastal sands: Porto Rico; Hispaniola; Balamas; Curacao.

ELAPHRIUM SIMARUBA (L.) Rose

Common on the coastal plain and on the plateau: Porto Rico; Hispaniola; Bahamas; Curacao.

STIGMAPHYLLON LINGULATUM (Poir.) Small

Common on the coastal plain and on the plateau: Porto Rico; Hispaniola.

BYRSONIMA LUCIDA (Sw.) L. C. Rich

Occasional on the coastal plain: Porto Rico; Hispaniola; Bahamas.

XYLOPHYLLA EPIPHYLLANTHUS (L.) Britton. (Phyllanthus Epiphyllanthus L.)

Common on the coastal plain: Porto Rico; Hispaniola; Bahamas.

PHYLLANTHUS NIRURI L.

Cultivated ground, coastal plain. Not collected: Porto Rico; Hispaniola; Bahamas; Curacao.

CROTON LUCIDUS L.

Common on the coastal plain and on the plateau: Porto Rico; Hispaniola; Bahamas.

\section{CROTON DISCOLOR Willd.}

Common on the plateau: Porto Rico; Hispaniola.

CROTON BETULINUS Vahl

Common on the coastal plain and on the plateau: Porto Rico; Hispaniola.

ARGITHAMNIA CANDICANS Sw.

Common on the coastal plain and on the plateau: Porto Rico; Hispaniola; Bahamas; Curacao.

RICINUS COMMUNIS L.

Waste grounds, Ubero: Native of the Old World tropics. 


\section{HIPPOMANE MANCINELLA L.}

Common on the coastal plain: Porto Rico; Hispaniola; Bahamas; Curacao.

CHAMAESYCE MONENSIS Millsp.

Limestone plateau, Ubero: Endemic.

CHAMAESYCE PORTORICENSIS (Urban) Millsp.

On limestone rocks, Ubero and Sardinera: Porto Rico.

CHAMAESYCE SERPENS (HBK.) Small

Moist soil, coastal plain and plateau: Porto Rico.

CHAMAESYCE HYPERICIFOLIA (L.) Millsp.

Common in cultivated ground on the coastal plain: Porto Rico; Hispaniola; Bahamas; Curacao.

CHAMAESYCE BUXIFOLIA (Lam.) Small

Common on coastal sands: Porto Rico; Hispaniola; Bahamas; Curacao.

AKLEMA PETIOLARIS (Sims) Millsp. (Euphorbia petiolaris Sims.) Common on the coastal plain and on the plateau: Porto Rico.

POINSETTIA HETEROPHYLLA (L.) Kl. \& Garcke

Sandy beach, Playa de Fajaro: Porto Rico; Hispaniola; Bahamas.

\section{PEDILANTHUS LATIFOLIUS Millsp. \& Britton, sp. nov.}

Shrubby, about 6 feet high, the young branches zig-zag, puberulent. Leaves ovate to ovate-orbicular, 4.5 inches long or less, very nearly sessile, dull-green, acute at the apex, roundish or subcordate at the base, very inconspicuously veined, glabrous, the midrib elevated but not keeled beneath. Inflorescence terminal, cymose, puberulent, bracteate; bracts lanceolate, acute, 3.5-4 x 2 lin., somewhat exceeding the peduncles; involucre about $10 \times 4.5$ lin., glabrous without and within, tube narrow anteriorly, main lobes lanceolate-oblong, rounded obtuse, ciliate at the apex, the accessory lobes equal or nearly so connivent with the main lobes to near the ciliate apices, fifth lobe elongate-ligulate, truncate ciliate, somewhat shorter than the accessory lobes and nearly closing the superior fissure of the tube; appendix large, strongly saccate, about one-third the length of the tube, split for half its length into two sarcous, ligulate slightly grooved and emarginate lobes; glands 4, of two sorts: the upper pair reniform at the summit of a broadly triangular stipe which is connivent with the surface of the appendix, anterior margins free and sharp; lower pair about one-half the size of the upper, discoid, peltate on a very short, free pedicel. Male pedicels numerous, glabrous; female pedicel glabrous; ovary glabrous; style 3 -lobed at the apex, the stigmatic branches bifid. Fruit unknown.

Castle Point, Bermuda (Brown \& Britton, 820, TYPE). Near Bath, Jamaica (Britton, 3491). Baracoa, Cuba (Bemis). Sanchez, Santo Domingo (Rose, Fitch \& Russell, 4397). Mona Island (Britton, Cowell \& Hess, 1786). Perhaps indigenous at the Santo Domingo locality citcd; at all the others an evident escape from cultivation, or in gardens.

METOPIUM TOXIFERUM (L.) Krug \& Urban

Common on the coastal plain and on the plateau: Porto Rico; Hispaniola; Bahamas.

COMOCLADIA DODONAEA (L.) Urban

Frequent on the plateau: Porto Rico; Hispaniola.

RHACOMA CRỌSSOPETALUM L.

Frequent on the coastal plain and on the plateau: Porto Rico; Hispaniola; Bahamas; Curacao.

GYMINDA LATIFOLIA (Sw.) Urban

Occasional on the coastal plain: Porto Rico; Hispaniola; Bahamas. 
SCHAEFFERIA FRUTESCENS Jacq.

Common on the coastal plain: Porto Rico; Hispaniola; Bahamas.

CARDIOSPERMUM MICROCARPUM HBK.

Bahamas.

Frequent on the coastal plain and on the plateau: Porto Rico; Hispaniola;

HYPELATE TRIFOLIATA Sw.

Coastal plain near Sardinera: Porto Rico; Hispaniola; Bahamas.

EXOTHEA PANICULATA (Juss.) Radlk.

Base of limestone cliffs, Sardinera: Porto Rico; Hispaniola; Bahamas.

DODONAEA EHRENBERGII Schl.

Common on the coastal plain and on the plateau: Hispaniola; Bahamas.

KRUGIODENDRON FERREUM (Vahl) Urban

Occasional on the coastal plain: Porto Rico; Hispaniola; Bahamas; Curacao.

REYNOSIA UNCINATA Urban

Frequent on the plateau: Porto Rico.

SARCOMPHALUS TAYLORI Britton

Occasional on the coastal plain: Bahamas.

COLUBRINA COLUBRINA (L.) Millsp.

Occasional along the base of the cliffs, coastal plain: Porto Rico; Hispaniola; Bahamas.

CISSUS TRIFOLIATA L.

Coastal thickets: Porto Rico; Hispaniola; Bahamas; Aruba.

CORCHORUS SILIQUOSUS L.

Occasional on the coastal plain: Porto Rico; Hispaniola; Bahamas.

CORCHORUS HIRSUTUS L.

Common on the coastal plain and on the plateau: Porto Rico; Hispaniola; Bahamas; Curacao.

ABUTILON UMBELLATUM (L.) Sweet

Frequent on the coastal plain: Porto Rico; Hispaniola; Curacao.

GAYOIDES CRISPUM (L.) Small

Occasional on the coastal plain: Porto Rico; Hispaniola; Bahamas.

MALVASTRUM SPICATUM (L.) A. Gray

Cultivated ground, coastal plain: Porto Rico; Hispaniola; Curacao.

SIDA SPINOSA L. Curacao.

Cultivated ground, coastal plain: Porto Rico; Hispaniola; Bahamas;

SIDA GLABRA Mill. (S. ulmifolia Cav.)

Frequent on the coastal plain: Porto Rico; Hispaniola.

SIDA PROCUMBENS Sw.

Occasional on the coastal plain: Porto Rico; Hispaniola; Bahamas; Curacao.

SIDA ACUMINATA DC. Bahamas.

Frequent on the coastal plain and on the plateau: Porto Rico; Hispaniola;

BASTARDIA VISCOSA (L.) HBK.

Occasional on the coastal plain: Porto Rico; Hispaniola; Bahamas; recorded from Curacao.

MALACHRA CAPITATA L.

Occasional in cultivated ground, coastal plain: Porto Rico; Hispaniola. 
PARITIUM TILIACEUM (L.) Juss.

Border of a swamp, Sardinera: Porto Rico; Hispaniola; Bahamas.

GOSSYPIUM BARBADENSE I.

Spontaneous after cultivation on the coastal plain. Apparently not native.

MELOCHIA TOMENTOSA L.

Common on the coastal plain and on the plateau: Porto Rico; Hispaniola; Baliamas; Curacao.

\section{WALTHERIA AMERICANA L.}

Occasional on the coastal plain and on the plateau: Porto Rico; Hispaniola; Bahamas; Curacao.

AYENIA PUSILLA L.

Frequent on the coastal plain: Porto Rico; Hispaniola; Bahamas.

HELICTERES JAMAICENSIS Jacq.

Frequent on the coastal plain and on the plateau: Porto Rico; Hispaniola; Bahamas.

CLUSIA ROSEA Jacq.

Common on the coastal plain and on the plateau: Porto Rico; Hispaniola; Bahamas.

CANELLA IVINTERANA (L.) Gaertn.

Common on the coastal plain and on the plateau: Porto Rico; Hispaniola; Bahamas.

\section{TURNERA DIFFUSA Willd.} Bahamas.

Occasional on the coastal plain and on the plateau: Porto Rico; Hispaniola;

PASSIFLORA SUBEROSA L.

Common on the coastal plain and on the plateau: Porto Rico; Hispaniola; Bahamas; Curacao.

PASSIFLORA FOETIDA L.

Sandy veach, Playa de Fajaro: Porto Rico; Hispaniola; Bahamas; Curacao.

CARICA PAPAYA L.

Common on the coastal plain about Sardinera, apparently established after cultivation. A race with small globose fruits. Original home unknown.

HARRISIA PORTORICENSIS Britton

Common on the talus and on the plateau: Porto Rico.

CEPHALOCEREUS ROYENI (L.) Britton \& Rose

Common on the plateau: Porto Rico [St. Thomas to Antigua].

CACTUS INTORTUS Mill. (Melocactus portoricensis Suringar.)

Common on the plateau: Porto Rico [St. Thomas to Antigua].

CORYPHANTHA NIVOSA (Link) Britton. (DIamillaria nivosa Link.)

Very abundant on the plateau: Culebra [St. Thomas to Tortola; Antigua]; Bahamas.

OPUNTIA CATACANTHA Link \& Otto

Common on the plateau; occasional on the coastal plain: Porto Rico [St. Thomas to Antigua].

OPUNTIA TAYLORI Britton

Top of cliff near Sardinera: Santo Domingo; Culebra [St. Thomas to Tortola].

OPUNTIA DILLENII (Ker.) Haw.

Common on the coastal plain and on the plateau. Not collected: Porto Rico; Hispaniola; Bahamas. 
TERMINALIA CATAPPA L.

Occasional on coastal sands: Porto Rico; Hispaniola; [spontaneous after cultivation in the Bahamas].

\section{CONOCARPUS ERECTA L.}

Occasional in coastal sands: Porto Rico; Hispaniola; Bahamas; Curacao.

BUCIDA BUCERAS L.

Coastal woods, Ubero: Porto Rico; Hispaniola; Bahamas.

LAGUNCULARIA RACEMOSA (L.) Gaertn. Curacao.

Borders of marshes, coastal plain: Porto Rico; Hispaniola; Bahamas;

CALYPTRANTHES PALLENS (Poir.) Griseb.

Base of cliffs, Ubero: Porto Rico (?) ; Hispaniola; Bahamas.

EUGENIA BUXIFOLIA (Sw.) Willd.

Common on the coastal plain and on the plateau: Porto Rico; Hispaniola; Bahamas.

\section{EUGENIA AXILLARIS (Sw.) Willd.}

Frequent or occasional on the coastal plain, at the base of cliffs and on the plateau: Porto Rico; Hispaniola; Bahamas.

EUGENIA RHOMBEA (Berg.) Krug. \& Urban Bahamas.

Coastal plain between Sardinera and Ubero: Porto Rico; Hispaniola;

ANAMOMIS FRAGRANS (Sw.) Griseb.

Occasional on the coastal plain: Porto Rico; Hispaniola. Recorded from the Baliamas.

JACQUINIA BARBASCO (Loefl.) Mez.

Common in coastal thickets and occasional on the coastal plain: Porto Rico; Hispaniola; Curacao.

? DIPHOLIS

Coastal plain, Sardinera. A tree about $12 \mathrm{~m}$. high, in foliage only.

BUMELIA OBOVATA (Lam.) DC.

Frequent on the coastal plain. Not in flower or fruit at the time of our visit: Porto Rico; Hispaniola; Curacao.

PLUMIERA OBTUSA L.

Common on the coastal plain and on the plateau: Hispaniola; Bahamas.

RAUWOLFIA TETRAPHYLLA L. ( $R$. nitida Jacq.)

Frequent on the coastal plain and on the plateau: Porto Rico; Hispaniola; Bahamas.

ECHITES AGGLUTINATA Jacq.

Occasional on the coastal plain and on the plateau: Porto Rico; Hispaniola.

URECHITES LUTEA (L.) Britton

Occasional on the coastal plain: Porto Rico; Hispaniola; Bahamas.

METASTELMA (undetermined)

Coastal rocks, Ubero.

METASTELMA (undetermined)

Occasional on the coastal plain and on the plateau.

EVOLVULUS GLABER Spreng.

Moist soil, coastal plain: Porto Rico; Hispaniola; Bahamas; Curacao. 
JACQUEMIONTIA JAMAICENSIS (Jacq.) Hall. f.

Occasional on coastal sands: Porto Rico; Hispaniola; Bahamas.

JACQUEMIONTIA PENTANTHA (Jacq.) D. Don

Frequent on the coastal plain and on the plateau: Porto Rico; Hispaniola; Bahamas; Curacao.

OPERCULINA AEGYPTIA (L.) House

Cultivated ground, coastal plain: Porto Rico; Hispaniola; Curacao.

? EXOGONIUM MICRODACTYLUM (Griseb.) House

Occasional on the plateau. Specimen insufficient for certain determination.

IPOMOEA PES-CAPRAE (L.) Roth.

Common on coastal sands: Porto Rico; Hispaniola; Bahamas; Curacao.

IPOMOEA TRILOBA L.

Frequent in cultivated ground on the coastal plain: Porto Rico; Bahamas.

CALONYCTION GRANDIFLORUM (Jacq.) Choisy. (Ipomoea tuba G. Don.) Frequent in coastal thickets: Porto Rico; Hispaniola; Bahamas; Curacao.

VARRONIA GLOBOSA Jacq.

Occasional on the coastal plain: Porto Rico; Hispaniola; Bahamas; Curacao.

BOURRERIA SUCCULENTA Jacq.

Common on the coastal plain and on the plateau: Porto Rico; Hispaniola; Curacao.

MALLOTONIA GNAPHALODES (L.) Britton.1 (Tournefortia gnaphalodes R. Br.)

Common on coastal sands: Porto Rico; Hispaniola; Bahamas; Curacao.

TOURNEFORTIA HIRSUTISSIMA L.

Base of limestone cliffs, Sardinera: Porto Rico; Hispaniola.

TOURNEFORTIA MICROPHYLLA Bert.

Common on the coastal plain and on the plateau: Porto Rico; Hispaniola.

\section{HELIOTROPIUM CRISPIFLORUM Urban}

Moist soil, coastal plain: Porto Rico. Closely resembles the Porto Rico plant but is lower and with shorter internodes; no flowering specimens were obtained.

\section{HELIOTROPIUM PARVIFLORUM L.}

Frequent on the coastal plain: Porto Rico; Hispaniola; Bahamas; Curacao.

LANTANA SCABRIDA Ait.

Collected by Professor Stevens, not found by us: Porto Rico; Hispaniola. Apparently specifically distinct from $L$. Camara $\mathrm{L}$.

LANTANA INVOLUCRATA L.

Common on the coastal plain and on the plateau: Porto Rico; Hispaniola; Bahamas; Curacao.

VALERIANODES JAMAICENSIS (L.) Medic

Common on the coastal plain and on the plateau: Porto Rico; Hispaniola; Bahamas; Curacao.

VALERIANODES STRIGOSA (Vahl) Kuntze

Frequent on the coastal plain and on the plateau: Porto Rico; Hispaniola.

'Mallotonia (Griseb.) Britton, gen, nov.

Tournefortia Section Mallotonia Griseb. Fl. Brit. W. I. 483. 1861.

Type species: Tournefortia gnaphalodes (L.) R. Br. 
SALVIA SEROTINA L. (S. micrantha Vahl)

Frequent on the coastal plain and on the plateau: Porto Rico; Hispaniola; Bahamas.

HYPTIS PECTINATA (L.) Poit.

Cultivated ground on the coastal piain: Porto Rico; Hispaniola; Bahamas; Curacao.

SOLANUM NIGRUM L. (S. americanum Mill.)

Cultivated ground, Sardinera: Porto Rico; Hispaniola; Bahamas; Curacao.

SOLANUM VERBASCIFOLIUM L.

Occasional at the bases of cliffs and on the coastal plain: Porto Rico; Hispaniola; Bahamas.

BRAMIA MONNIERIA (L.) Drake. (Herpestis Monniera HBK.)

Border of a pool, Sardinera: Porto Rico; Hispaniola; Bahamas.

CAPRARIA BIFLORA L.

Common on the coastal plain and on the plateau: Porto Rico; Hispaniola; Bahamas; Curacao.

\section{SCOPARIA DULCIS L}

In moist soil on the coastal plain: Porto Rico; Hispaniola; Bahamas.

TABEBUIA HETEROPHYLLA (DC.) Britton. (Raputia (?) heterophylla DC.; Tabebuia triphylla DC., not Bignonia triphylla L.)

Frequent on the coastal plain and on the plateau. Leaves l-foliolate to 5-foliolate: Porto Rico.

TABEBUIA LUCIDA Britton, sp. nov.

A tree up to $5 \mathrm{~m}$. high. Leaves $3-5$-foliolate; petioles slender, lepidote, $6 \mathrm{~cm}$. long or less; petiolules of the larger, upper leaflets slender, lepidote, $8-20 \mathrm{~mm}$. long; lower leaflets sessile or nearly so; leaflets thin-coriaceous, narrowly oblong or oblong-oblanceolate, 5-10 cm. long, 1-3 cm. wide, shining, reticulate-veined and lepidote on both sides, rather abruptly acute or obtusish at the apex, narrowed or obtuse at the base; flowers clustered; pedicels lepidote; calyx about $14 \mathrm{~mm}$. long, 2-lipped; corolla pink, glabrous, about $5 \mathrm{~cm}$. long, its cylindric tube $5-6 \mathrm{~mm}$. long, its narrowly eampanulate throat about $3 \mathrm{~cm}$. long, its limb about $1.5 \mathrm{~cm}$. long, the lobes nearly entire.

Limestone cliffs, Sardinera, Mona Island, Porto Rico (Britton, Cowell and Hess, 1686 ).

\section{SESAMUM ORIENTALE L.}

Cultivated ground, coastal plain. Native of the East Indies.

BLECHUM BROWNEI Juss.

Shaded rocks, Sardinera: Porto Rico; Hispaniola; Bahamas.

JUSTICTA PERIPLOCIFOLIA Jacq. paniola.

Occasional on the coastal plain, a narrow-leaved race: Porto Rico; His-

JUSTICIA PECTORALIS Jaeq.

Border of pool, Sardinera: Porto Rico; Hispaniola.

PLANTAGO MAJOR L.

Cultivated ground, coastal plain. Not collected. Native of the Old World.

EXOSTEMA CARIBAEUM (Jacq.) R. \& S.

Frequent on the coastal plain and on the plateau: Porto Rico; Hispaniola; Bahamas.

RANDIA ACULEATA L.

Common on the coastal plain and on the plateau: Porto Rico; Hispaniola; Bahamas; Curacao. 
GUETTARDA ELLIPTICA Sw.

Occasional on the coastal plain: Porto Rico; Hispaniola; Bahamas.

STENOSTOMUM ACUTATUM DC.

Frequent on the coastal plain and on the plateau: Porto Rico; Curacao.

ERITHALIS FRUTICOSA L.

Common on sand dunes, on the coastal plain and occasional on the plateau: Porto Rico; Hispaniola; Bahamas; Curacao.

CHIOCOCCA ALBA (L.) Hitche.

Occasional on the coastal plain and on the plateau: Porto Rico; Hispaniola; Balıamas.

STRUMPFIA MARITIMA Jacq.

Limestone plateau near Ubero, frequent: Porto Rico; Hispaniola; Bahamas; Curacao.

PSYCHOTRIA UNDATA Jacq.

Occasional on the coastal plain: Porto Rico; Hispaniola; Bahamas.

ERNODEA LITTORALIS Sw.

Common on coastal sands: Porto Rico; Hispaniola; Bahamas; Bonaire.

SPERMACOCE TENUIOR L.

Frequent on the coastal plain: Porto Rico; Hispaniola; Bahamas; Curacao.

CUCUMIS ANGURIA L.

Cultivated ground, Sardinera: Porto Rico; Hispaniola; Curacao.

EUPATORIUM ODORATUM L.

Common on the coastal plain: Porto Rico; Hispaniola; Bahamas.

EUPATORIUM ATRIPLICIFOLIUM Lam.

Coastal rocks, Sardinera: Porto Rico; recorded from Hispaniola and from the Bahamas.

LEPTILON PUSILLUM (Nutt.) Britton

Common in waste and cultivated grounds, coastal plain: Porto Rico; Hispaniola (?); Bahamas.

LEPTILON BONARIENSE (L.) Small

Cultivated ground, Sardinera: Porto Rico; Hispaniola.

PLUCHEA PURPURASCENS (Sw.) DC.

Borders of marshes, coastal plain: Porto Rico; Hispaniola; Bahamas.

BORRICHIA ARBORESCENS (L.) DC.

Occasional on coastal rocks: Porto Rico; Hispaniola; Bahamas.

WEDELIA PARVIFLORA L. C. Rich

Common on the coastal plain: Porto Rico.

ELEUTHERANTHERA RUDERALIS (Sw.) Sch. Bip.

Cultivated ground, coastal plain: Porto Rico; Hispaniola. Erroneously recorded from the Bahamas.

BIDENS CYNAPIIFOLIA HBK.

Collected by Professor Stevens, not found by us: Porto Rico; Hispaniola; Bahamas; Curacao.

\section{PTERIDOPHYTA}

(Determined by Miss Margaret Slosson)

ADIANTUM FRAGILE Sw.

Limestone cliff, Sardinera: Porto Rico; Hispaniola. 


\section{ACROSTICHUM AUREUM L.}

Border of pool near Sardinera. Determined from barren leaf specimen: Porto Rico; Hispaniola; Bahamas; Curacao.

CYCIOPELTIS SEMICORDATA (Sw.) J. Smith

Shaded limestone rocks, Sardinera: Porto Rico; Hispaniola.

\section{MUSCI}

(Determined by Elizabeth G. Britton and R. S. Williams)

THUIDIUM INVOLVENS (Hedw.) Mitt.

On dead wood and shaded rocks: Porto Rico; Hispaniola.

TORTULA AGRARIA Sw.

On the ground near Sardinera: Porto Rico; Hispaniola; Bahamas.

HYOPHILA GUADELUPENSIS Broth.

Wet soil on the coastal plain between Sardinera and Ubero: Guadeloupe; Montserrat.

\section{BRYUM MICRODECURRENS E. G. Britton}

Wet soil on the coastal plain between Sardinera and Ubero: St. Thomas.

CALYMPERES RICHARDI C. Muell.

On tree trunks, base of cliff, Sardinera: Porto Rico; Hispaniola; Bahamas.

CALYMPERES (an apparently undescribed species)

On Bourreria, Ubero; Hispaniola.

\section{HEPATICAE \\ JUNGERMANNIACEAE}

(Determined by Professor A. W. Evans)

BRACHIOLEJEUNEA BAHAMENSIS Evans

On limestone, Ubero; on trunk of Gymnanthes, Sardinera: Bahamas.

MASTIGOLEJEUNEA AURICULATA (Wils. \& Hook.) Schiffn.

On shaded limestone and on dead wood, Sardinera: Porto Rico; Bahamas.

LEJEUNEA (barren and undeterminable)

On shaded limestone, bark and dead wood.

FRULLANIA SQUARROSA (R. B. \& U.) Dumort.

On trunks and logs on the coastal plain: Porto Rico; Bahamas.

FRULLANIA (barren and undeterminable)

On dead wood, Sardinera.

\section{RICCIACEAE}

(Contributed by Dr. Marshall Avery Howe)

\section{RICCIA BRITTONII, sp. nov.}

Thallus simple or once dichotomous, forming irregularly gregarious patches, oblong-ovate, linguiform, or obovate, $2-5 \mathrm{~mm}$. x 1-2 mm., subacute or obtuse, conspicuously alveolate-reticulate and light green above, with a scarious-albescent border 80-175 $\mu$ wide, concolorous or very commonly brownish laterally and ventrally; median sulcus deep and acute except in older parts; ventral scales small, inconspicuous, hyaline, rarely exceeding the thin membranous ascending thallusmargins; transverse sections mostly 1.5-2.0 times as wide as high, the ventral outlines semi-orbicular in younger parts, becoming flattened in the older; cells of the primary dorsal epidermis cylindric dome-shaped or subhemispheric, soon collapsing, leaving shallow slightly indurated more or less persistent cup-like vestiges; monoecious; antheridial ostioles scarcely elevated; spores brown, becoming subopaque, soon exposed, $100-145 \mu$ in maximum diameter, rather ob- 
scurely or sometimes distinctly angled, often flattened, destitute of wing-margins, almost uniformly areolate over the whole surface, with age showing in profile obtuse or truncate papillae 3-5 $\mu$ long, areolae mostly 10-18 $\mu$ wide.

On wet, sunny soil, accompanied by $R$. violacea, between Sardinera and Ubero, Mona Island, February, 1914, Britton, Cowell, \& Hess, 1749a.

Riccia Brittonii exhibits certain points of contact with Riccia sorocarpa Bisch. and $R$. dictyospora M. A. Howe. ${ }^{1}$ It is close to $R$. sorocarpa in vegetative characters, though differing in the wider, more pronounced, scarious-albescent thallusmargins and slightly in the character of the epidermis, but it departs widely from this species in the spores, which are much larger (100-145 $\mu$ vs. 70-90 $\mu$, max. diam.), are destitute of wing-margins, and commonly have the areolae of the inner faces almost as well and regularly developed as those of the outer face. From Riccia dictyospora, the species differs in the less elongate thallus (2-5 $\mathrm{mm}$. vs. 4-10 $\mathrm{mm}$.), the albescent instead of dark purple thallus-margins and scales, the more semicircular and less parabolic outlines of transverse sections of the thallus, and in the larger spores (100-145 $\mu$ vs. 95-116 $\mu$, max. diam.), with larger areolae (10-18 $\mu$ vs. 8-12 $\mu$.

RICCIA VIOLACEA, sp. nov.

Thallus simple or 1-3 times dichotomous, irregularly gregarious, $1.5-4.0 \mathrm{~mm}$. long, the main segments oblong-obovate or linguiform, $0.65-1.15 \mathrm{~mm}$. broad, rather obscurely and finely areolate and dark green above, dark violet or blackish at margins and on sides, this color encroaching on the surface here and there, especially in the older parts and at the sinuses; median sulcus shallow or obsolete except at apex; ventral scales very short or rudimentary, dark violet, rarely overlapping, commonly divided into a series of small irregular often tooth-like lamellae, each consisting of only a few cells; transverse sections plano-convex, somewhat flattened-semiorbicular, or occasionally biconvex, 1.5-2.0 times as wide as high; the margins obtuse or rounded, bearing especially toward the apex numerous or occasional violet or sometimes hyaline conic or subcylindric acute or obtuse papillae 30-110 $\mu$ long and 25-45 $\mu$ broad at base; cells of the primary dorsal epidermis subhemispheric or mammiform, soon collapsing and leaving inconspicuous vestigia; remaining parts unknown.

On wet, sunny soil, accompanied by Riccia Brittonii, between Sardinera and Ubero, Mona Island, February, 1914, Britton, Cowell, \& Hess, 17496.

In size, habit, and color, $R$. violacea is somewhat suggestive of $R$. nigrella DC., but the thallus has papillae or very short cilia at the margins, which are wanting in $R$. nigrella, the scales are much smaller, more rudimentary and more divided than in $R$. nigrella, and the cells of the primary epidermis are much less persistent. Its nearest affinity is doubtless with $R$. atromarginata Levier, which is known from Sicily, Sardinia, and Greece; from this it appears to differ (if one may judge from the descriptions alone) in the obtuse thallus-margins, the very short, rudimentary, divided, rarely overlapping scales, and the commonly violet papillae which are confined to the margins and sides while in $R$. atromarginata the hyaline incurved "pili" are said to cover also the anterior dorsal surface.

\section{LICHENES}

(Determined by Professor Lincoln W. Riddle)

\section{ARTHOPYRENIA}

On Coccolobis obtusifolia, Ubero.

PYRENULA

On bark, Sardinera.

MELANOTHECA CRUENTA (Mont.) Muell. Arg. On Gymnanthes, Sardinera.

TRYPETHELIUM ELUTERIAE Spreng.

On Pithecolobium, Sardinera, and on Coccolobis obtusifolia, Ubero.

${ }^{1}$ Bull. Torr. Bot. Club 28: 163. 1901. 
'TRYPETHELIUM MASTOIDEUM Ach.

On Pithccolobium, Sardinera.

TRYPETHELIUM OCHROLEUCUM Nyl.

On Zanthoxylum, between Sardinera and Ubero.

OPEGRAPHA

On Ficus, Sardinera; on Calyptranthes, Ubero.

GRAPHIS AFZELII Ach.

On Zanthoxylum, between Sardinera and Ubero; on Pithecolobium, Sardinera.

\section{GRAPHIS}

Collected by Professor Stevens.

\section{CHIODECTON}

On Plumiera, Sardinera.

\section{LEPTOTREMA}

On dead wood, Sardinera.

CLADONIA FIMBRIATA var. CONIOCRAEA (Floerke) Wainio On dead $\log$, Sardinera.

OMPHALARIA LINGULATA Tuck.

On limestone, Sardinera.

OMPHALARIA POLYGLOSSA Nyl.

On exposed limestone, Ubero.

\section{OMPHALARIA}

On limestone, Ubero.

\section{COLLEMA}

On limestone rocks, Sardinera.

LEPTOGIUM (sterile and indeterminable) On Torrubia, Sardinera.

PARMELIA TINCTORUM Despv. On a tree trunk.

PARMELIA SULPHURATA Nees and Flot. On a dead log, Sardinera.

RAMALINA MONTAGNEI De Not. On a twig, Sardinera. Collected also by Professor Stevens.

RAMALINA COMPLANATA (Sw.) Ach. On a twig, Sardinera.

PYXINE PICTA (Sw.) Tuck.

On Pithecolobium, Sardinera; on Zanthoxylum, between Sardinera and Ubero.

PHYSCIA SPECIOSA (Wulf.) Nyl. (A small form) On Ficus, Sardinera.

PHYSCIA ALBA Fee On Calyptranthes, Ubero; also, not typical, on Torrubia, Sardinera.

The collection also contains a sterile plant near Omphalaria Wrightii Tuck., from wet, sunny soil between Sardinera and 
1915]

Ubero, a sterile species of the Dermatocarpaceae growing on limestone at Ubero, and three other sterile and undeterminable specimens.

\section{BASIDIOMYCETES}

(Determined by Dr. W. A. Murrill)

LENTINUS CRINITUS (L.) Fries

On dead wood, Ubero: Porto Rico; Bahamas.

SCHIZOPHYLLUM ALNEUM (L.) Schroet.

Frequent on dead wood: Porto Rico; Bahamas.

DAEDALEA AMANITOIDES Beauv.

On dead wood, Ubero: Porto Rico; Bahamas.

INONOTUS CORROSUS Murr.

On dead wood, Sardinera: Porto Rico; Bahamas.

PYROPOLYPORUS DEPENDENS Murr.

On dead wood: Porto Rico; Bahamas.

POGONOMYCES HYDNOIDES (Sw.) Murr.

On dead wood: Porto Rico; Bahamas.

PYCNOPORUS SANGUINEUS (L.) Murr.

Frequent on dead wood at base of escarpment: Porto Rico; Bahamas.

CORIOLOPSIS RIGIDA (Berk. \& Mont.) Murr.

On dead wood, Sardinera: Porto Rico; Bahamas.

CORIOLUS PINSITUS (Fries) Pat.

On dead wood: Porto Rico; Bahamas.

XYLARIA

On dead log, Ubero.

\section{UREDINALES}

(Determined by Professor J. C. Arthur)

COLEOSPORIUM PLUMIERAE Pat.

On Plumiera obtusa.

KUEHNEOLA GOSSYPII (Lagerh.) Arth.

On Gossypium barbadense.

PUCCINIA CENCHRI Dietr. \& Holw.

On Cenchrus.

PUCCINIA CRASSIPES B. \& C.

On Ipomoea triloba $\mathrm{L}$.

PUCCINIA EUPHORBIAE P. Henn.

On Aklenea petiolaris (Sims) Millsp.

PUCCINIA INFLATA Arth.

On Stigmaphyllon lingulatum (Poir.) Small

PUCCINIA LATERITIA B. \& C.

On Ernodea littoralis Sw. 
PUCCINIA URBANIANA P. Henn.

On Valerianodes strigosa (Vahl) Kuntze

UREDO BIOCELLATA Arth.

On Pluchea purpurascens (Sw.) Kuntze

UREDO CAMELIAE Mayor.

On Chaetochloa setosa.

Many parasitic fungi collected by Professor Stevens have not yet been determined.

\section{ALGA}

(Determined by Professor N. Wille)

SCYTONEMA OCELLATUM Lyngb.

Flat limestone plateau, Ubero.

\section{RECAPITULATion}

Species indicated in the foregoing list. . . . . . . . . . . . 292

Deduct thallophytes (distribution little known) ........ 47

Deduct undetermined and doubtfully determined species..... 12

Deduct certainly introduced species............... 8

Deduct endemic species..................... 4

In common with Porto Rico...............

In common with Porto Rico. . . . . . . . . . . . . . 211

" " " Hispaniola ............. 185

" " " $"$ Bahamas ............... 155

" " $"$ Curacao ............... 87

Species other than Endemio Ones and Thallophytes not known on Porto Rico (including Desecheo, Culebra AND Vieques)

Cenchropsis myosuriodes: Bahamas; Cuba.

Domingoa hymenodes: Hispaniola; Cuba.

Caesalpinia domingensis : Hispaniola.

Guilandina melanosperma: St. Croix.

Dodonaea Ehrenbergii : Bahamas; Hispaniola; Cuba. 
Sarcomphalus Taylori: Bahamas.

Plumiera obtusa: Hispaniola; Bahamas; Cuba.

Brachiolejeunea bahamensis: Florida; Bahamas.

Hyophila guadelupensis: Guadeloupe; Montserrat. Bryum subdecurrens: St. Thomas. 


\section{Explanation of Plate}

\section{PLATE 1}

Fig. 1. Escarpment, Mona Island, showing openings of caves.

Fig. 2. Part of Mona Island from the ocean, showing escarpments and plateau. 


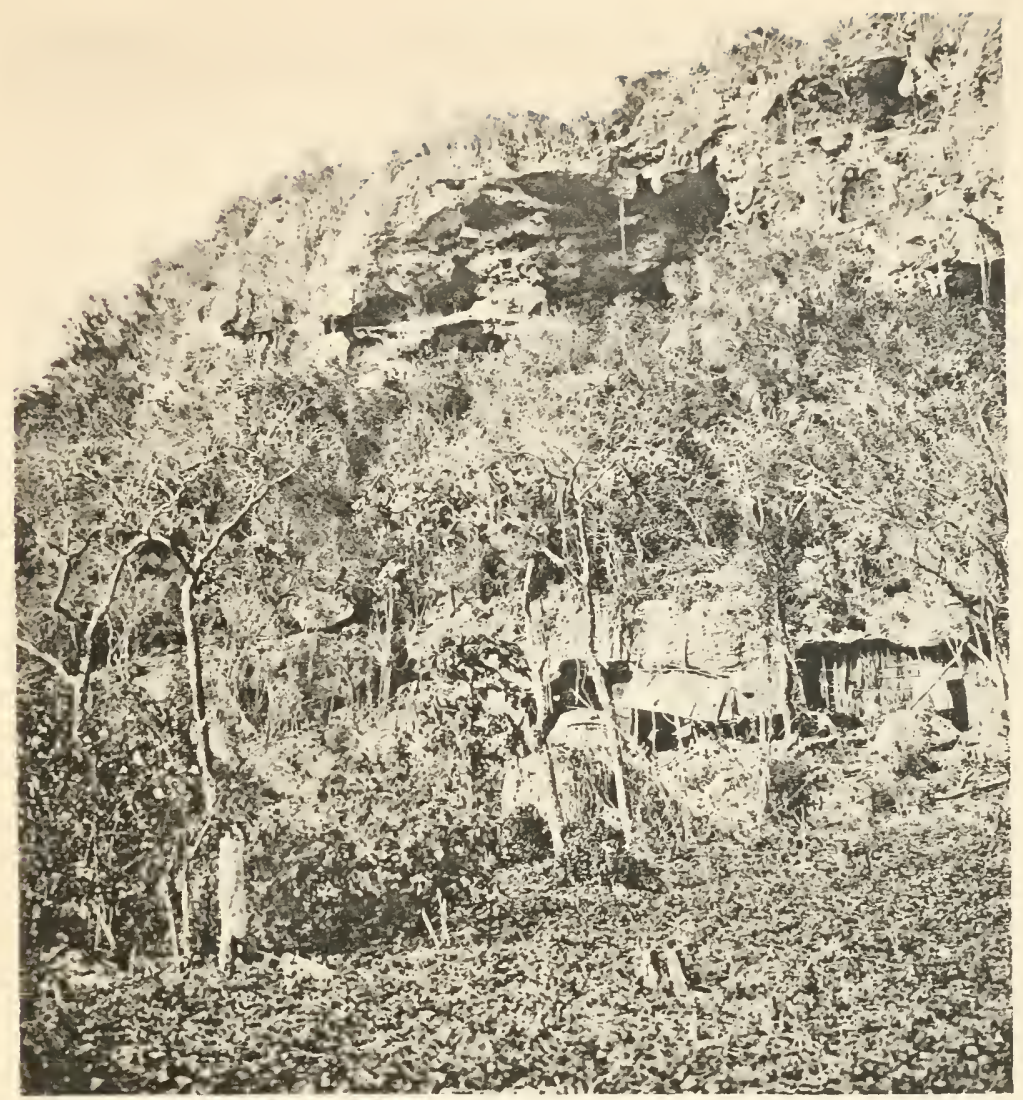

Fig. 1

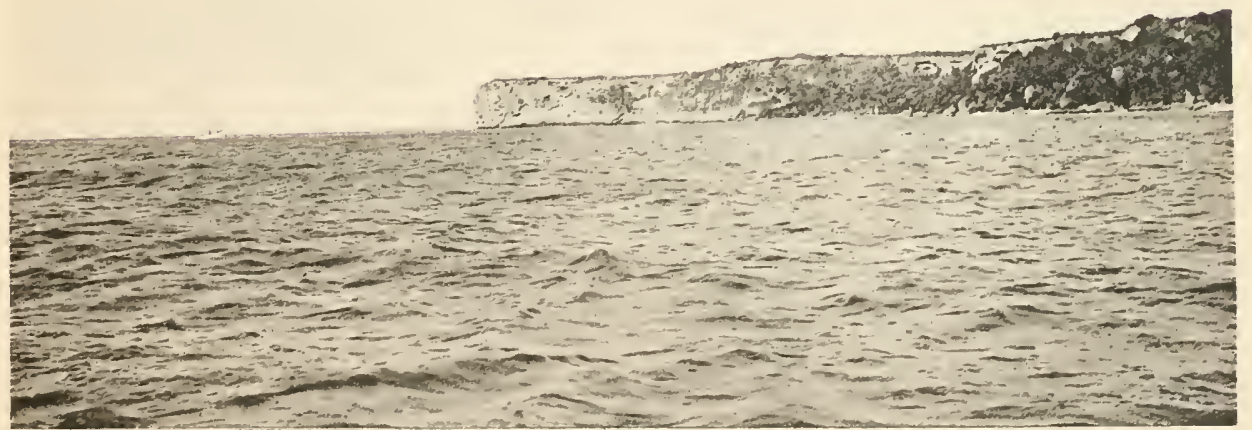

Fig. 2

BRITTON-VEGETATION OF MONA ISLAND 


ANNALS OF THE MISSOURI BOTANICAL GARDEN

\section{Explanation of Plate}

PLATE 2

Fig. 1. Escarpment and tables, Mona Island.

Fig. 2. Coastal thicket, Mona Island. 


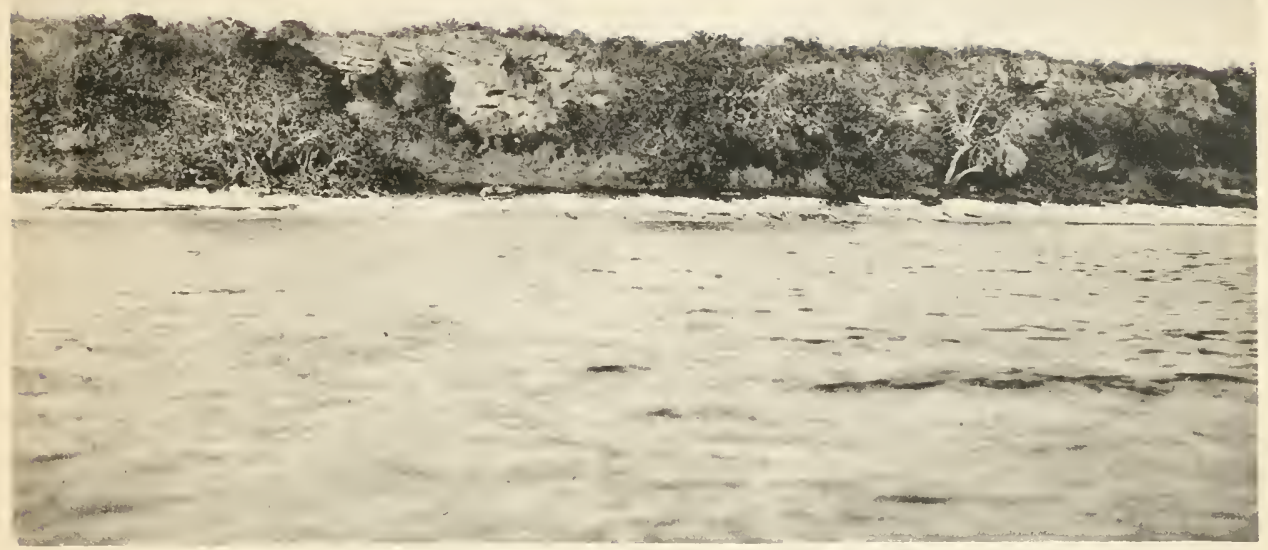

Fig. 1

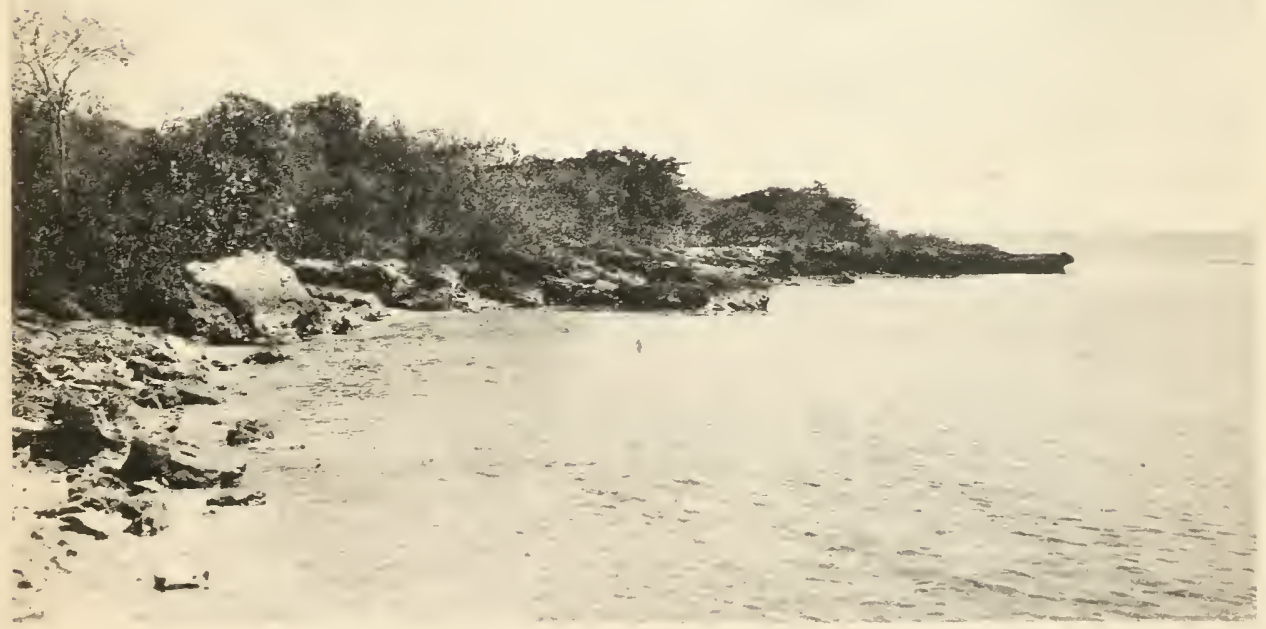

Fig. 2

BRITTON-VEGETATION OF MONA ISLAND 





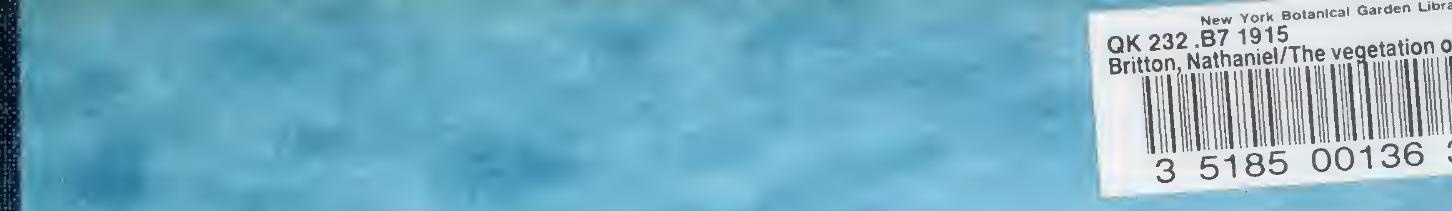




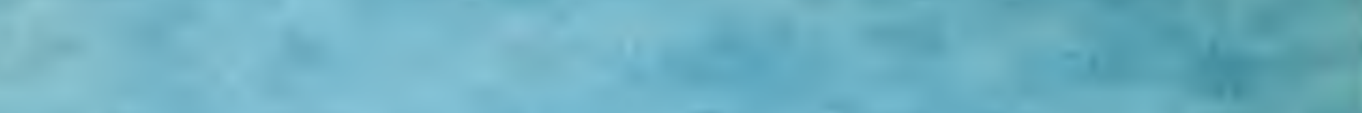

1
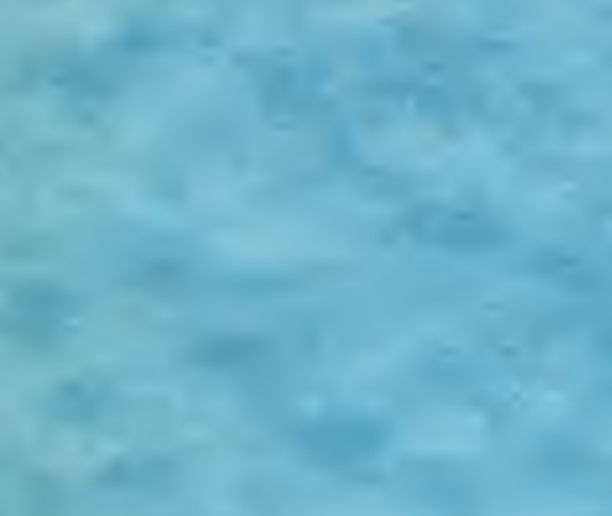

$x^{2}=x^{2}$
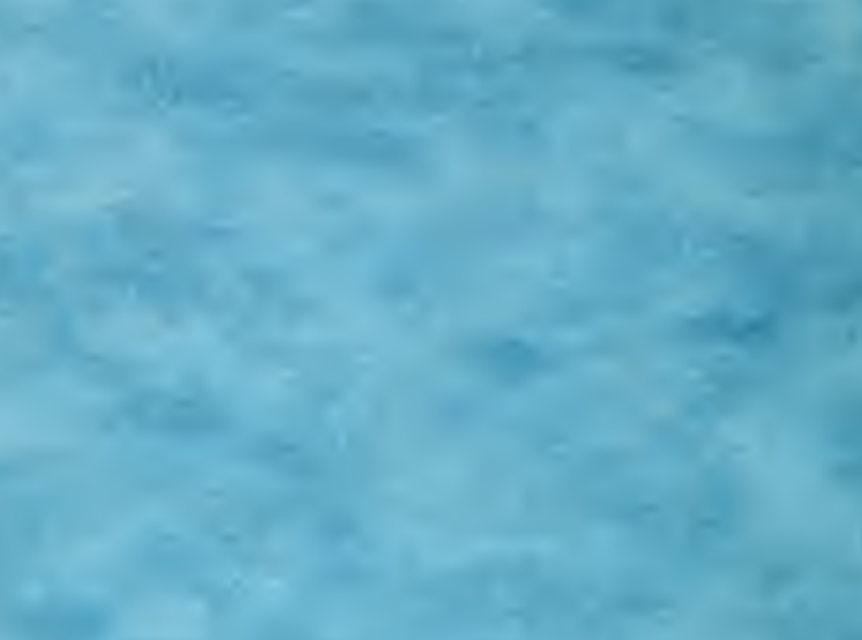